\title{
Effect of Cement Dust on Lung Function of Adult Cement Loaders in Benin City, Nigeria
}

\author{
${ }^{1}$ OMIGIE, M; *2AGOREYO, F; ${ }^{3}$ AGBONTAEN, L \\ Department of Physiology, School of Basic Sciences, College of Medical Sciences, University of Benin, Benin City, Edo State, Nigeria \\ *Corresponding Author Email Address: agoreyofo@yahoo.com
}

\begin{abstract}
Cement is one of the important construction materials used for housing and infrastructure development. It is made from a mixture of clay and limestone that is calcined in kiln. The aim of this research is to investigate the effect of cement dust on lung function of adult cement loaders in Benin City using a total of 60 apparently healthy male and female subjects divided into two groups (experimental and control) of thirty subjects each between the ages of 25-40 years after ethical clearance. Anthropometric and Spirometry measurements were carried out on all subjects and data appropriately documented. Results obtained show reduction in the forced vital capacity of the experimental group (3.0L and $1.0 \mathrm{~L})$ compared to the control(1.0L).The forced expiratory volume in one second was reduced for the experimental group compared to the control( $3.2 \mathrm{~L} / \mathrm{Second}$ and $1.0 \mathrm{~L} /$ second respectively).The peak expiratory flow rate of the experimental group were reduced well when compared to the control $(5.0 \mathrm{~L}$ and $0.5 \mathrm{~L}$ respectively).The results were statistically significant $(\mathrm{P}<0.05)$, hence cement loaders are advised to wear protective gadgets.
\end{abstract}

\section{DOI: $\underline{\text { https://dx.doi.org/10.4314/jasem.v23i8.27 }}$}

Copyright: Copyright $(02019$ Omigie et al. This is an open access article distributed under the Creative Commons Attribution License (CCL), which permits unrestricted use, distribution, and reproduction in any medium, provided the original work is properly cited.

Dates: Received: 25 June 2019; Revised: 13 August 2019; 30 August 2019

Keywords: Cement, Lung function, Spirometry, Peak Expiratory flow rate

Cement is one of the important construction materials needed for housing and infrastructure development manufactured from the mixture of clay and limestone that is calcined in kiln. Portland cement silicate is a class of hydraulic cements containing tri- and dicalcium silicate $\left(2 \mathrm{CaO} . \mathrm{SiO}_{2}\right.$ and $\left.3 \mathrm{CaO} . \mathrm{SiO}_{2}\right)$ in addition to aluminium, tricalcium aluminate and iron oxide. The final product usually contains silicate compounds ( $75 \%$ calcium silicates), $5-10 \%$ calcium aluminates, $5 \%$ calcium sulfate, $2-4 \%$ magnesium oxide, but little or no quartz. Production of cement is a dusty industrial process which increases the risk of occupational hazard to exposed workers. The effect of cement dust on the respiratory system has been extensively studied (Alakija et al., 1990; Noor et al., 2000; Laraqui et al., 2001; Al-Neaimi et al., 2001; Meo et al., 2002; Mwaiselage et al., 2005). Therefore, the increasing demand for cement and associated products in Nigeria, has arose a need to investigate the health risk of cement dust exposure on the workers. The aim of this research is to investigate the effect of cement dust on lung function of cement loaders.

\section{MATERIALS AND METHOD}

Study Area: This study will be carried out in the metropolitan city of Benin, Edo State, south-south Nigeria. 60 adult male and female subjects within the ages of 25-40 years who had worked for a minimum of one year participated in this study. They were divided into two groups of 30 subjects each (experimental and control). The control group consist of apparently healthy adult male and female not exposed to cement dust. Subjects excluded from this study include those with deformities of the thoracic cage, vertebral column, musculoskeletal system, known cases of neuromuscular diseases, gross anaemia, diabetes mellitus, chronic obstructive pulmonary diseases, malignancy, drug addicts and cigarette smokers.

Informed consent were obtained from all subjects and Ethical approval obtained from Ethics and Research Committee of UBTH Benin City. Anthropometric measurements which include age, sex, height, chest circumference were done on all subjects. The weights of the subjects were obtained using weight balance while the height was measured using a meter tape rule.

Measurement of Lung Function: Lung function test was done using a digital spirometer (Spirolab 111) which is in accordance with the American. Thoracic Society (ATS) (2003). Spirometry was carried out with the subject in sitting position, and subjects asked to take a deep breath and thereafter asked to forcefully blow into the spirometer while pinching the nose.Three manoeuvres were done and the highest of them taken and recorded appropriately.Forced vital capacity (FVC), forced expiratory volume in one second $\left(\mathrm{FEV}_{1}\right)$ and peak expiratory flow (PEFR) were determined for all subjects.

All the tests were performed between the hours of $9 \mathrm{am}$ and11am in the morning to minimize diurnal variation (Glindmeyer et al., 1994). The precise 
technique in executing various tests for the study was based on the operational manual of the instrument, which was also calibrated daily and operated at an ambient room temperature of between $26-28^{\circ} \mathrm{C}$. All data were appropriately recorded.

Statistical Analysis: The results were computed statistically using one way Analysis of Variance (ANOVA), using Statistical Package of Social Science (SPSS) software Version 2.0, post hoc test was performed for inter group comparison using LSD.The result expressed as mean + Standard error of mean (SEM). Values of $\mathrm{P}<0.05$ were considered statistically significant.

\section{RESULT AND DISCUSSION}

This research revealed that there was reduction in lung functions $\left(\mathrm{FEV}_{1}, \mathrm{PEFR}\right.$ and $\left.\mathrm{FVC}\right)$ of cement loaders exposed to cement dust compared with control groups $(\mathrm{P}<0.05)$. This is in line with the work done by Marwan et al.,(2015), Cavariani et al., (2005) who also reported a reduction in Forced Vital Capacity (FVC), Forced Expiratory Volume at 1.0 second $\left(\mathrm{FEV}_{1}\right), \mathrm{FVC} / \mathrm{FEV}_{1}$ and Peak Expiratory Flow Rate (PEFR) of workers exposed to cement dust compared to control groups.

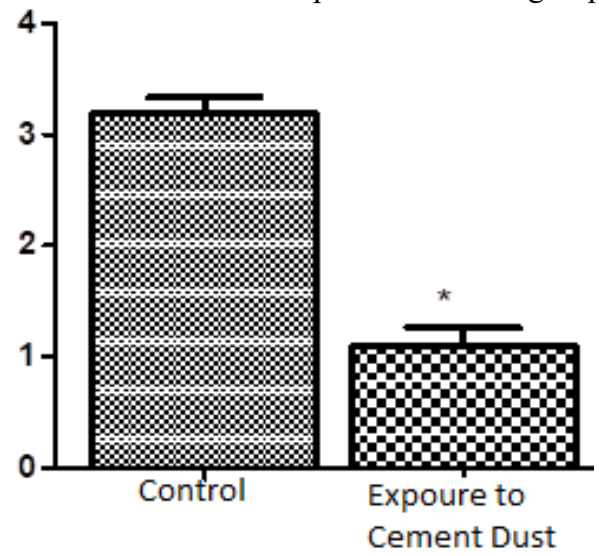

Fig 1: Forced vital capacity of cement loaders exposed to cement dust and control. There was a significant differences in the forced vital capacity of cement loaders exposed to cement dust compared with control $(\mathrm{p}<0.05)$.

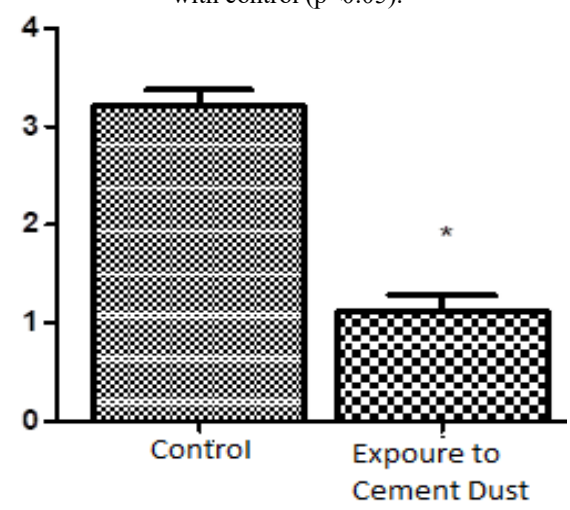

Fig 2: Forced expiration volume in one second of cement loaders exposed to cement dust and control. There was significant differences in the forced expiration volume in one second of cement loaders exposed to cement dust compared with control $(\mathrm{p}<0.05)$.

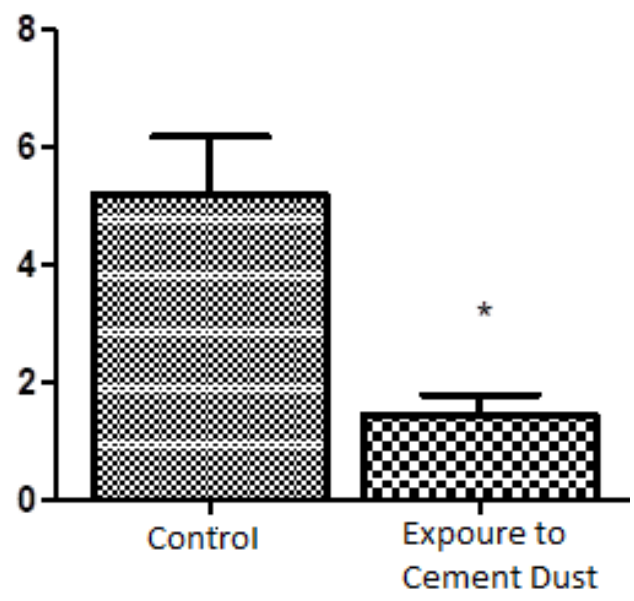

Fig 3: Peak expiratory flow rate of cement loaders exposed to cement dust and control. There was a significant difference in the peak expiratory flow of cement loaders exposed to cement dust compared with control $(\mathrm{p}<0.05)$.

A number of other studies have also found decreased lung function of cement loaders, and other occupations with heavy dust exposure. An Italian study found that cement workers exposed to cement dust had reduced lung function according to spiromectric data (Cavariani et al., 2005). Nwibo et al., (2012) also reported significant decreases in $\mathrm{FEV}_{1}, \mathrm{FVC}$ and PEFR among quarry workers exposed to dust.This reduction can be attributed to the size and degree of exposure to the dust. Cement dust when inhaled, due to their size are able to penetrate down the respiratory zone of the respiratory tract and excite inflammatory reactions, which result in the production of mucous and exudate. Accumulation and consolidation of mucous along the airway result in the narrowing and healing by fibrosis of the respiratory tract, which may be responsible for the reduction in respiratory parameters.

Vermeulen et al., implicated reduction in lung function parameters in the aetiology of pulmonary diseases (Vermeulen et al., 2002). These and other negative health effects of dust exposure have been widely reported especially in underdeveloped countries like Nigeria (Beaucham et al., 2012).

Conclusion: This study has shown that exposure to cement dust has deleterious effect on lung function, hence proper safety precautions need to be adhered to in other to avoid or minimize these hazards.

\section{REFERENCES}

Alakija, W; Igewe, VJ; Jarikre, LN; Chiwuzie, JC (1990). Ventilatory function of workers at Okpella Factory in Nigeria. West Africa $J$. Medic. 9(3):187-193.

Beaucham, CC; Lentz, TJ; Rice, FL (2012). Expanding control banding for workplace silica 
exposures throughout the Americas. International J. Occupational Environ. Health 18: 344-347.

Cavariani, F; Carneiro, AP; Leonori, R; Bedini, L; Quercia, A; Forastiere, F (2005). Silica in ceramic Industry: Exposure and pulmonary diseases. General Italian Medical Lav. Ergon. 27: 300 - 302.

Glindmeyer, HW; Lefante, JJ; Robert, NJ; Roy, JR. (1994). Cotton dust and across-shift change in $\mathrm{FEV}_{1}$ as preditors of annual change in $\mathrm{FEV}_{1}$. Am. J. Resp. Critical Care Medic. 149(3):90584.

Marwan, MD; Khaled, MB; Ashraf, MA; Kendra, KS; Shawn, GG. (2015). Lung Function Impact from Working in the Pre-Revolution Libyan Quarry Industry. Inter. J. Environ. Res. Pub. Health 12: 5006-5012.
Mwaiselage, J; Bratveit, M; Moen, BE; Mashalla, Y (2005). Respiratory symptoms and chronic obstructive pulmonary disease among cement factory workers. Scand J. Work Environ. Health 31(4):23-316.

Noor, H; Yap CL; Zolkepli, O; Faridah, M (2000). Effect of exposure to dust on lung function of cement factory workers. Med. J. Malaysia 55(1):7-51.

Nwibo, AN; Ugwuja, EI; Nwambeke, NO; Emelumadu, OF; Ogbonnaya, LU (2012). Pulmonary problems among quarry workers of stone crushing industrial site at Umuoghara, Ebonyi State, Nigeria. Inter. J. Occur. Environ. Medic. 3: 178-185.

Vermeulen R, Heederik D, Kromhout H, Smit HA (2002). Respiratory symptoms and occupation: a cross-sectional study of the general population. Environmental Health; 1:1-5. 